\title{
Replacement of Chemical Fertilizer by Beverage Sludge to Reduce Environmental Pollution
}

\section{Md. Abul Hasanath ( $\nabla$ engr.hasanath@gmail.com )}

Dhaka University of Engineering and Technology Faculty of Civil Engineering https://orcid.org/00000002-7500-591X

\section{Ganesh Chandra Saha}

DUET: Dhaka University of Engineering and Technology

\section{Md. Siddique Alam}

Bangladesh Agricultural Research Institute

\section{Md. Nashir Uddin}

DUET: Dhaka University of Engineering and Technology

\section{Research}

Keywords: Beverage sludge, chemical fertilizer, environmental pollution, cultivation, periodical growth, food value, nutrients

Posted Date: June 9th, 2021

DOl: https://doi.org/10.21203/rs.3.rs-531460/v1

License: (c) (i) This work is licensed under a Creative Commons Attribution 4.0 International License. Read Full License 


\section{Abstract}

Wastewater generation from beverage industries is on the rise as the demand and consumption surge worldwide. The typical ingredients of beverages are carbonated water, saccharides, sweetener, fruit pulp, flavoring agent, color, preservatives, and salts. Only $20 \%$ concentration of the mixture goes to the bottle and the remaining becomes wastewater. However, nutrients and organics remain in wastewater and are left in sludge after going through ETP. The presence of these nutrients makes the beverage sludge useful for the cultivation that can not only decrease the application of chemical fertilizers but also combat the environmental pollution. Indian spinach and Okra have been cultivated in six different mixtures containing beverage sludge and soil to study their effects on growth, yield, food value and nutrient. Soil nutrients, organic content, $\mathrm{EC}$, and $\mathrm{pH}$ have been analyzed to assess the suitability of sludge for cultivation. The control treatment was designed by $100 \%$ soil and gradually $20,40,60,80$ and $100 \%$ soil were replaced by beverage sludge in other treatments. The maximum growth of Indian Spinach and Okra was observed $120 \%$ and $125 \%$ higher at 38 days after sowing on the treatment of $80 \%$ sludge and $20 \%$ soil compared to the control treatment. Similarly, the maximum yield of Indian spinach and Okra was computed to be nine and two times higher than the control on the same treatment. Food values (ascorbic acid, $\beta$ - carotene, and protein) and nutrients ( $\mathrm{Fe}, \mathrm{Ca}, \mathrm{Mg}, \mathrm{K}, \mathrm{P}$ and $\mathrm{Zn}$ ) were found to increase with the increasing amount of beverage sludge while those satisfy the standards of USDA. Without using any kind of fertilizer in low grade soil, the beverage sludge has shown the potentiality in both growth and yield. It turns out that beverage sludge can be used as a substitute for chemical fertilizer with an optimum amount of $80 \%$.

\subsection{Introduction}

Beverage is a drinkable liquid intended to be used for human consumption. It can be alcoholic and nonalcoholic with forms of ready to drink (RTD) and made to dilute (MTD). In addition to their basic purpose of nourishing thirst- beverage supplies calories, fat, and nutrients. The demand, production and consumption are increasing with a forecasted expansion rate of $5.3 \%$ CAGR by 2025 [1]. It is obvious that much more wastewater is going to be generated from beverage manufacturing units leading to the huge volume of sludge from the effluent treatment plants (ETPs). Sludge management is an important issue for environmental protection although several reuse methods are being practiced.

The key ingredient of soft drink beverages is carbonated water, which constitutes up to $90 \%$ to $94 \%$ in soft drinks where diet soft drink contains $99 \%$ [2], [3]. In terms of fruit and milk-based beverages, the volume of water depends on the individual and unique formula. Since it is harmless, non-toxic, and relatively cheap and easy to liquefy, carbon dioxide is an ideal gas for beverages. Other ingredients of beverage include sucrose, lactose, glucose, fructose, artificial sweeteners, fruit pulp, flavoring agents, coloring agents, preservatives, and mineral salts. Only $20 \%$ of the concentrated mixture goes to a beverage pack (edible) while $70 \%$ becomes wastewater, $9 \%$ gets lost due to evaporation, and $1 \%$ water losses in spent grains and tubs [4]. Although these amounts may vary depending on the formulas of individual beverage manufacturers, nutrients remain in wastewater because of usage of food grade 
ingredients and organics during beverage production. A fewer number of inorganic ingredients may also be found. Nutrients and organics are left behind in sludge after going through ETP which may be helpful to cultivable soil.

Global food demand and production are being driven up by population growth. Improvement in agricultural productivity on a long term basis to meet the growing food demand in the face of soil quality is the vital concern for the agricultural sector around the globe [5]. The global production of crops and vegetables needs to be increased with the mounting demand. There are few available options which are being followed by nations to achieve the maximum productivity i.e., expanding arable land, increasing the frequency of cultivation and boosting yields [6]. In Bangladesh, food grain and vegetable production are increasing each year though the total cultivable land is not increasing proportionately [7], [8]. As the selfreplenishment of soil fertility has become almost nil these days, it is difficult to cultivate in it without making it fertile. Therefore, chemical fertilizers are being used to fertilize the cultivable lands. Application of chemical fertilizer is one of the easiest practices to enhance soil fertility leading to increasing use of inorganic fertilizer each year to boost the crop productivity. Moreover, most of the cultivable land of Bangladesh contains less than $1.7 \%$ organic content while the recommended amount is at least $3.4 \%$ [9]. It is worth noting that the amount of chemical fertilizers applied to the soil was 4.049 million metric ton in FY of 2011-12 which sequentially increased up to 5.575 million metric ton in FY of 2018-19 in Bangladesh [8].

Chemical fertilizer is agricultural pollutants leading to several ways of soil, water, and air quality degradation. Heavy metal is one of the major pollutants coming from fertilizers [10]. Because of their non-biodegradable nature, which allows them to readily accumulate in tissues and living organisms, high concentrations can cause phytotoxicity and damage human health [11]. Not only does heavy metal cause degradation to soil and water, excess amounts of nutrients and organics can make conditions unfavorable to other living organisms. These agricultural pollutants are often mixed to water sources by runoff as a non-point source of pollution. High nutrient concentrations stimulate algae growth leading to imbalanced aquatic ecosystems, which can experience phytoplankton blooms, eutrophication, production of excess organic matter, and an increase in oxygen consumption leading to oxygen depletion and death benthic organisms that live on or near the seabed. The detrimental effects of chemical fertilizers begin with the manufacture of these compounds, the byproducts of fertilizer factories are poisonous chemicals and gases such as $\mathrm{NH}_{4}, \mathrm{CO}_{2}, \mathrm{CH}_{4}$ etc. which can pollute air. Moreover, wastes of fertilizer manufacturing is also a point of concern because it can lead contamination to the environment. In short, not only the fertilizer polluting environment but also the fertilizer industry is responsible for it.

This study, therefore, illustrates that beverage sludge may be a viable alternative to fertilizer for improving fertility of cultivable land because it contains requisite nutrients and organic contents. Thus, this study could introduce a safe management technique for beverage sludge through reducing use of chemical fertilizer and thereby can mitigate environmental pollution.

\subsection{Methodology}




\subsubsection{Collection of beverage sludge and other materials}

Habiganj Industrial Park (HIP) is one of the major industrial zones of Bangladesh and PRAN Foods Limited is a local beverage manufacturer having a beverage production plant at HIP that exports its products to more than 110 countries [12]. Different kinds of beverages e.g., carbonated soft drinks, fruit juices and milk-based drinks (locally known as Lassi) are being produced here. A biological ETP is being operated to treat the wastewater that is generated from beverage production. Beverage sludge was collected from the ETP of the PRAN's beverage. In this study, soil was collected from arable land of Bangladesh Agricultural Research Institute (BARI) in which beverage sludge was experimented as the substitution of chemical fertilizers. Furthermore, the effects of beverage sludge on the cultivation of Indian Spinach (Basella alba L.) and Okra (Abelmoschus esculentus L.) were studied through pot experiment in summer. One leafy and fruit vegetable was selected to determine the effects of beverage sludge. The latest variety of vegetable seeds was collected from BARI and they were BARI Puishak 2 and BARI Dherosh 2 for Indian spinach and Okra respectively [13].

\subsubsection{Characterization of beverage sludge and soil}

Physical and chemical characteristics of beverage sludge and soil have been measured for beverage sludge and soil. Specific gravity was determined following ASTM D854-14 whereas bulk density was measured according to the core sampling method respectively [14], [15]. Additionally, samples were sieved through $0.42 \mathrm{~mm}$ and diluted by distilled water in a weight ratio of 1:1.25 to determine $\mathrm{pH}$ and EC [16].

Organic carbon $(\mathrm{OC})$ content was determined by the wet oxidation method, also known as the photometric method [17], [18]. Beverage sludge and soil were air dried and sieved through $0.5 \mathrm{~mm}$ sieve. 1 $\mathrm{g}$ of soil and beverage sludge sample were taken into a $250 \mathrm{~mL}$ Erlenmeyer flask separately. $10 \mathrm{~mL}$ $\mathrm{K}_{2} \mathrm{Cr}_{2} \mathrm{O}_{7}$ of $1 \mathrm{~N}$ and $10 \mathrm{~mL} \mathrm{H} \mathrm{SO}_{4}$ of $5 \mathrm{~N}$ were added to the solution of flasks. The solution was stirred for 10 minutes at $180 \mathrm{rpm}$ in a horizontal shaker. A little amount of deionized water was added to adjust the volume of supernatant solution and absorption was measured by UV-Vis spectrophotometer to compute OC. On the other hand, some of the crop growing nutrients were also tested for beverage sludge and soil samples. Essential soil nutrients i.e., nitrogen, phosphorus and potassium were tested according to Kjeldahl [19], Bray and Kurtz [20] and flame photometric [21] methods respectively. The sulfur content was determined according to the turbidity method [22]. Other micronutrients i.e., $\mathrm{Fe}, \mathrm{Mn}, \mathrm{Ca}, \mathrm{Mg}$ and $\mathrm{Zn}$ were determined using atomic absorption spectrophotometer (AAS) from both sludge and soil. The nutrients were extracted from beverage sludge and soil by the digestion process using aqua regia [23]. A mixture of aqua regia and $5 \mathrm{~g}$ sample was kept overnight, heated to boiling point for two hours and filtered through Whatman filter paper at room temperature. The concentrations of $\mathrm{Fe}, \mathrm{Mn}, \mathrm{Ca}, \mathrm{Mg}$ and $\mathrm{Zn}$ were measured by AAS after calibration by standard solutions.

\subsubsection{Experiment design and cultivation}


Six different volumetric mixtures of beverage sludge and soil have been studied in this study. Soil from pots was gradually replaced by beverage sludge in different treatments. The replacements of soil by beverage sludge were $20 \%, 40 \%, 60 \%, 80 \%$ and $100 \%$ respectively. $100 \%$ of the soil was considered as a control treatment. Six replications of each combination were designed to analyze critically. A plastic polythene-covered shade ( $18 \mathrm{~m}$ long and $3 \mathrm{~m}$ wide) was built to make a controlled environment so that rainwater infiltration could not hamper the study. In short, there were 36 pots for Indian spinach and 36 for Okra cultivation without using fertilizer to observe the genuine effects of beverage sludge on cultivation. Four seeds of Indian spinach and two of Okra were sowed in each pot initially. However, two healthy sprouts of Indian spinach and one of Okra were kept in the pot after thinning out since all sowed seeds did not germinate.

Table 1 Combinations of beverage sludge and soil

\begin{tabular}{|c|c|c|c|c|c|}
\hline \multirow{2}{*}{$\begin{array}{l}\text { Treatment } \\
\text { ID }\end{array}$} & \multicolumn{2}{|c|}{ Combination } & \multirow{2}{*}{$\begin{array}{l}\text { No. of } \\
\text { replication }\end{array}$} & \multicolumn{2}{|c|}{ Dimension of pot $(\mathrm{cm})$} \\
\hline & $\begin{array}{l}\text { Soil } \\
\text { (volumetric } \\
\% \text { ) }\end{array}$ & $\begin{array}{l}\text { Beverage sludge } \\
\text { (volumetric \%) }\end{array}$ & & $\begin{array}{l}\text { Indian spinach } \\
\text { cultivation }\end{array}$ & $\begin{array}{l}\text { Okra } \\
\text { cultivation }\end{array}$ \\
\hline $\begin{array}{l}\mathrm{T}_{1} \mathrm{R}_{1} \\
\text { (control) }\end{array}$ & 0 & 100 & 6 & $\begin{array}{l}45 \mathrm{~cm} \text { diameter } \\
\text { and }\end{array}$ & $\begin{array}{l}20 \mathrm{~cm} \\
\text { diameter and }\end{array}$ \\
\hline $\mathrm{T}_{2} \mathrm{R}_{2}$ & 20 & 80 & 6 & $20 \mathrm{~cm}$ height & $22 \mathrm{~cm}$ height \\
\hline $\mathrm{T}_{3} \mathrm{R}_{3}$ & 40 & 60 & 6 & & \\
\hline $\mathrm{T}_{4} \mathrm{R}_{4}$ & 60 & 40 & 6 & & \\
\hline $\mathrm{T}_{5} \mathrm{R}_{5}$ & 80 & 20 & 6 & & \\
\hline $\mathrm{T}_{6} \mathrm{R}_{6}$ & 100 & 0 & 6 & & \\
\hline
\end{tabular}

\subsubsection{Growth observation, harvest, and yield computation}

Length of Indian spinach and height of Okra plant was recorded weekly to compare the periodical growth. The external portion from mud level to terminal bud of each plant was considered for counting the number of leaves and measuring the length. Periodical growth data logged for four weeks from the first day after sowing (DAS). Edible parts of Indian spinach (stem and leaf) and Okra were harvested for the first time at 38 and 44 days after sowing (DAS) respectively after maturation. It was harvested four times and it was stopped when there was nothing to be harvested from control treatments. The weight of edible parts of Indian spinach and Okra was computed during harvests. The yield value computed from the summation of the total harvest (four harvests).

\subsubsection{Food values measurement and toxic element detection}


In this study, a significant number of food values and nutrients were tested to analyze the effect of beverage sludge on the quality of vegetables. Nutrients ( $\mathrm{Fe}, \mathrm{Ca}, \mathrm{Mg}, \mathrm{K}, \mathrm{P}$ and $\mathrm{Zn}$ ) and food values (ascorbic acid, $\beta$-Carotene and protein) were tested from the sample prepared from the edible parts of the $1^{\text {st }}$ harvest of Indian spinach and Okra to measure their content. Ascorbic acid or vitamin-C of Indian spinach and Okra were determined according to the dichlorophenol- indophenol visual titration method [24]. $\beta$ - Carotene is a nutrient or provitamin which converts to vitamin- $A$ in the human body and it was tested using UV-Vis spectrophotometer [25]. Protein is a kind of energy source of the human body and helps to build tissues. To measure protein content, the amount of nitrogen present in vegetables was measured according to the Kjeldahl method and converted to protein using multiplication factor [26], [27]. Nutrients uptake were measured using atomic absorption spectrophotometer (AAS) after digesting the sample by aqua regia [23].

\subsection{Results And Discussion}

\subsubsection{Characteristics of beverage sludge and soil}

Bulk density and specific gravity are noticeable physical properties for agriculture which are factors for the healthy growth of plants. The bulk density of beverage sludge and soil was found $1.24 \mathrm{~g} \mathrm{cc}^{-1}$ and $1.89 \mathrm{~g} \mathrm{cc}^{-1}$ respectively (Table 2 ).

Table 2 Physical, physiochemical, and organic status of beverage sludge and soil

\begin{tabular}{|llll|}
\hline Parameter & Unit & Beverage Sludge & Soil \\
\hline Bulk density & $\mathrm{g} \mathrm{cc}^{-1}$ & 1.24 & 1.89 \\
\hline EC & $\mu \mathrm{S} \mathrm{cm}^{-1}$ & 1312 & 255 \\
\hline $\mathrm{pH}$ & - & 8.1 & 6.8 \\
\hline Organic content (OC) & $\%$ & 37.39 & 0.67 \\
\hline
\end{tabular}

According to USDA bulk density greater than $1.80 \mathrm{~g} \mathrm{cc}^{-1}$ affects root growth adversely and less than 1.60 $\mathrm{g} \mathrm{cc}^{-1}$ is favorable for most plant growth [28]. In this study, bulk density of beverage sludge assertively complies with USDA-NRCS recommendations whereas it is slightly higher in case of soil. On the other hand, specific gravity of beverage sludge is $40.43 \%$ lighter than utilized soil in weight. Lower specific gravity than conventional value indicates the possibility of organic content. The EC of beverage sludge and soil was found 1312 and $255 \mu \mathrm{S} \mathrm{cm}^{-1}$ respectively while EC of a good cultivable medium ranges from 200 to $1200 \mu \mathrm{S} \mathrm{cm}^{-1}$ [29], [30]. In this study, EC of beverage sludge was slightly higher than the standard range, which is not significant. On the other hand, the $\mathrm{OC}$ of beverage sludge and soil was found to be $37.37 \%$ and $0.67 \%$ respectively. Undoubtedly, OC of beverage sludge was found in an enriched state compared to soil whereas $3.4 \%$ is the minimum recommended amount [9]. Essential soil nutrients (NPK) and other important nutrients (S, Fe, Mn, Ca, Mg and Zn) concentration are presented in Table 3. 
Table 3 Crop growing nutrients in beverage sludge

\begin{tabular}{|llll|}
\hline Nutrient/ heavy metal & Unit & Beverage sludge & Soil \\
\hline Total nitrogen, $\mathrm{N}$ & $\%$ & 1.25 & 0.074 \\
\hline Phosphorus, $\mathrm{P}$ & $\%$ & 0.87 & 0.63 \\
\hline Potassium, $\mathrm{K}$ & $\%$ & 0.47 & 0.52 \\
\hline Sulfur, S & $\%$ & 0.76 & 0.072 \\
\hline Iron, Fe & $\mathrm{mg} \mathrm{kg}^{-1}$ & 11.80 & 10.00 \\
\hline Manganese, Mn & $\mathrm{mg} \mathrm{kg}^{-1}$ & 11.40 & 13.08 \\
\hline Calcium, Ca & $\mathrm{mg} \mathrm{kg}^{-1}$ & 12.63 & 10.52 \\
\hline Magnesium, Mg & $\mathrm{mg} \mathrm{kg}^{-1}$ & 4.88 & 3.10 \\
\hline Zinc, Zn & $\mathrm{mg} \mathrm{kg}^{-1}$ & 57.20 & 50.00 \\
\hline
\end{tabular}

NPKS of beverage sludge were found $1.25 \%, 1.15 \%, 1.88 \%$ and $0.76 \%$ respectively where $0.074 \%, 0.64 \%$, $0.47 \%$ and $0.0072 \%$ were found in soil. $\mathrm{N}$ and $\mathrm{P}$ functions for plant growth while $\mathrm{K}$ is responsible for osmosis and enzymatic activities with $\mathrm{S}$ being helpful for photosynthesis. Usually, nutritious chemical fertilizers like DAP, MOP, urea, and TSP are being used in soil to increase the amount of NPKS. Fe, Ca, Mg and $\mathrm{Zn}$ were found in a higher level than soil except $\mathrm{Mn}$ (Table 3). It is worth noting that the nutrient of beverage sludge is much better for cultivation compared to soil where fertilizer might be needed in terms of soil only.

However, beverage sludge can be applied to cultivable land because it is rich in organics and other plant growing nutrients. There are little chances of heavy metal presence because most ingredients being used are of food grade variety.

\subsubsection{Effects of beverage sludge on growth and harvest of cultivates}

The germination rate of Indian spinach and Okra was found to be $100 \%$. Weekly periodical growth was observed from the $1^{\text {st }}$ day after sowing (DAS) till the $1^{\text {st }}$ harvest. Periodical growth variation has been compared with control treatment $\left(T_{1} R_{1}\right)$ where beverage sludge was not mixed. The length or height and number of leaves are illustrated in Fig. 1 which is the average of six replications.

Length of Indian spinach and height of Okra gradually increased over time with treatment $T_{5} R_{5}(80 \%$ beverage sludge and $20 \%$ soil). The number of leaves of both cultivated plants has been found to increase with the increase in the amount of beverage sludge being used in pots. There is a proportional relation between the number of leaves and plant height. Notably, growth is a little bit lower than the 
maximum growth $\left(T_{5} R_{5}\right)$ at $T_{6} R_{6}$ where only beverage sludge was used for both cultivates. The amount of media, excessive nutrients and media texture may be the reason for that. However, growth of all treatments was found higher compared to control treatment $\left(T_{1} R_{1}\right)$ and the maximum growth was observed with $80 \%$ beverage sludge containing treatment.

From a previous study, the maximum length of Indian spinach was found $30 \mathrm{~cm}$ at 60 DAS when it was nourished by biogas plant residues (BPR) which was $64.5 \%$ higher than the control treatment [31]. This study of beverage sludge results in $42 \mathrm{~cm}$ as growth (length) at 38 DAS. In that case it is quite clear that beverage sludge is much healthier than BPR to be used in agricultural soil. On the other hand, sewage sludge was used in soil to study the effects on Okra in another study [32]. Number of leaves of the Okra plant was 24 when it was grown in $40 \%$ sewage sludge at 65 DAS but 23 leaves were totaled at 49 DAS using $60 \%$ sewage sludge. That means, an increase in the volume of sewage sludge reduces growth. Here, replacing $80 \%$ soil by beverage sludge causes 25 leaves at 49 DAS (Fig. 1). Beverage sludge causes decreased growth patterns if more than $80 \%$ sludge on the media.

Yield is an agricultural output, an important parameter to identify agricultural produce. In this study, Indian spinach and Okra were harvested at 38 DAS, 44 DAS, 65 DAS and 78 DAS. The yield illustrated in Fig. 4 is the summation of four harvests and averaged from replications. Weight of stems \& leaves of Indian spinach and fruits of Okra determined in harvests.

Yield of both cultivated vegetables has been found to increase with the increase in the volume of beverage sludge. The maximum yield of Indian spinach and Okra was observed with treatment $T_{5} R_{5}$ (where $80 \%$ soil of the pot was replaced by beverage sludge). $10.88 \mathrm{~kg} \mathrm{sqm}^{-1}$ yielded from Indian spinach whereas yield was only $1.16 \mathrm{~kg} \mathrm{sqm}^{-1}$ in the control treatment $\left(T_{1} R_{1}\right)$. On the other hand, the highest yield of Okra was $498.9 \mathrm{~g}$ per plant (14 fruits) with $\mathrm{T}_{5} \mathrm{R}_{5}$ but $302 \mathrm{~g}$ per plant (8 fruit) yielded from control treatment $\left(T_{1} R_{1}\right)$. The yield with $T_{6} R_{6}$ was $10.83 \mathrm{~kg} \mathrm{sqm}^{-1}$ and $324.4 \mathrm{~g}$ per plant (12 fruit) for Indian spinach and Okra respectively. That means, the agricultural output from $100 \%$ beverage is a little bit lower than the combination of $80 \%$ sludge and $20 \%$ soil. Previously, BPR were used for fertile cultivation of Indian spinach and the maximum yield was found to be $3.63 \mathrm{~kg} \mathrm{sqm}^{-1}$ [31]. Sing and Agarwal studied Okra where $111 \mathrm{~g}$ per plant and $150 \mathrm{~g}$ per plant were found as the yield from the treatment of $20 \%$ and $40 \%$ sewage sludge with soil, respectively [32].

\subsubsection{Food values and heavy metal uptake}

Food values i.e., ascorbic acid $\left(\mathrm{C}_{6} \mathrm{H}_{8} \mathrm{O}_{6}\right)$ or vitamin $\mathrm{C}$, $\beta$ - carotene $\left(\mathrm{C}_{40} \mathrm{H}_{56}\right)$ and protein have been tested from the edible parts of Indian spinach and Okra. The samples were prepared from the $1^{\text {st }}$ harvest.

From the analysis of food values i.e., ascorbic acid, $\beta$ - Carotene and protein of Indian spinach and Okra, it is observed that food values increased with the increase in the volume of beverage sludge (Fig. 5). Higher organic content of beverage sludge may be a reason for that because organic matter is a reservoir of nutrients that can be released over time. Ascorbic acid, $\beta$-carotene and protein contents of control 


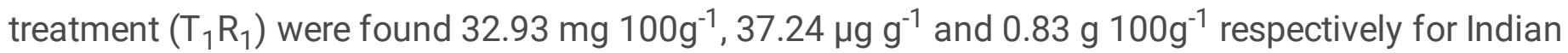

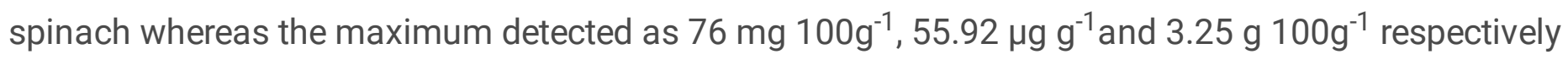
with $T_{6} R_{6}$. Similarly, the maximum content of ascorbic acid, $\beta$-carotene and protein from Okra was found

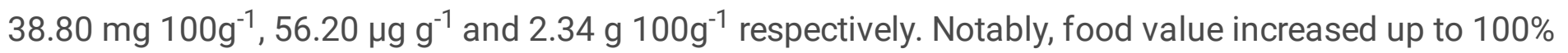
beverage sludge whereas maximum yield was found with the treatment of $80 \%$ beverage sludge and $20 \%$ soil $\left(T_{5} R_{5}\right)$.

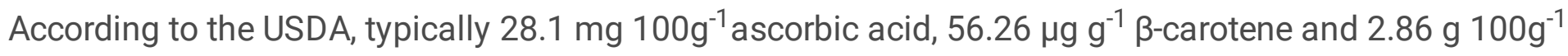

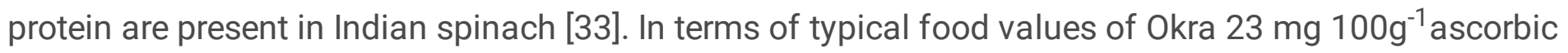

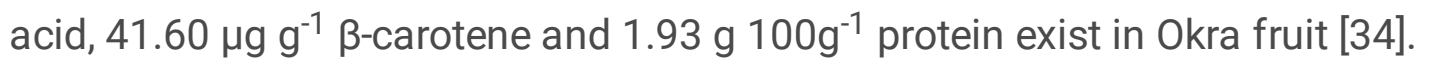

Table 4 Effects of beverage sludge on nutrients contents of the cultivates

\begin{tabular}{|c|c|c|c|c|c|c|c|c|}
\hline Plant & $\begin{array}{l}\text { Nutrients } \\
\left(\mathrm{mgkg}^{-1}\right)\end{array}$ & $\mathrm{T}_{1} \mathrm{R}_{1}$ & $\mathrm{~T}_{2} \mathrm{R}_{2}$ & $T_{3} R_{3}$ & $\mathrm{~T}_{4} \mathrm{R}_{4}$ & $T_{5} R_{5}$ & $T_{6} R_{6}$ & $\begin{array}{l}\text { Typical } \\
\text { values }^{\text {a }} \\
\text { b }\end{array}$ \\
\hline \multirow{6}{*}{$\begin{array}{l}\text { Indian spinach } \\
\text { (Basella alba) }\end{array}$} & $\mathrm{Fe}$ & 17.56 & 18.21 & 18.75 & 20.45 & 21.11 & 21.25 & 27.1 \\
\hline & $\mathrm{Ca}$ & 570.2 & 627.8 & 667.6 & 734.5 & 920.8 & 1013.6 & 990 \\
\hline & $\mathrm{Mg}$ & 411.07 & 497.5 & 641.8 & 713.3 & 848.2 & 879.8 & 790 \\
\hline & K & 3120.6 & 3040.2 & 2810.5 & 2680.5 & 2360.7 & 1750.4 & 5580 \\
\hline & $P$ & 402.8 & 413.4 & 427.7 & 441.3 & 463.7 & 528.9 & 490 \\
\hline & $\mathrm{Zn}$ & 8.2 & 13.4 & 22.2 & 19.7 & 22.9 & 23.1 & 5.3 \\
\hline \multirow{6}{*}{$\begin{array}{l}\text { Okra } \\
\text { (Abelmoschus } \\
\text { esculentus) }\end{array}$} & $\mathrm{Fe}$ & 4.83 & 5.39 & 5.97 & 6.59 & 7.12 & 7.64 & 6.2 \\
\hline & $\mathrm{Ca}$ & 496.2 & 523.8 & 595.2 & 631.7 & 714.5 & 788.5 & 820 \\
\hline & $\mathrm{Mg}$ & 365.7 & 398.4 & 434.3 & 467.7 & 495.6 & 526.4 & 570 \\
\hline & K & 2856.4 & 2848.8 & 2837.4 & 2828.6 & 2815.2 & 2789.4 & 2990 \\
\hline & $P$ & 476.2 & 489.5 & 504.4 & 528.4 & 535.6 & 586.1 & 610 \\
\hline & $\mathrm{Zn}$ & 13.8 & 18.4 & 21.2 & 20.1 & 18.9 & 18.4 & 5.8 \\
\hline
\end{tabular}

Sources: a, bUSDA central food database [33], [34]

Nutrients i.e., $\mathrm{Fe}, \mathrm{Ca}, \mathrm{Mg}, \mathrm{K}, \mathrm{P}$ and $\mathrm{Zn}$ were determined using the standard method described in the methodology. The positive effect of beverage sludge on nutrient values of cultivates is easily understandable here (Table 4). All concentrations of nutrients have been found to increase with the increasing amount of beverage sludge in pot except potassium (K). Measured nutrients were compared with the typical value of nutrients and found to be the same as the typicals [33], [34]. The important 
observation is that beverage sludge leads to a good quality crop without chemical fertilizer being needed. However, the more likely reason behind the uptake sequence of nutrients by Indian spinach and Okra is the contents of beverage sludge and the soil itself (Table 3). In short, uptakes gradually increased as the elements of media were increased. However, the substitution of beverage sludge by chemical fertilizer may be an optimum solution to reduce environmental pollution alongside increased food production.

\subsection{Conclusion}

Beverage sludge was used as an alternative to toxic chemical fertilizer (environmental pollutant), where Indian spinach and Okra have been cultivated in six different mixtures of beverage sludge and soil. Beverage sludge characteristics meet vegetable cultivation requirements. Bulk density, EC, pH, organic content and crop growing nutrients ( $\mathrm{N}, \mathrm{P}, \mathrm{K}, \mathrm{S}, \mathrm{Fe}, \mathrm{Ca}, \mathrm{Mg}$, and $\mathrm{Mn}$ ) were tested for both beverage sludge and soil. All the tested parameters were found to suit cultivation conditions having a notable content of organics (37.69\%). With 100\%, germination growth of Indian spinach was $63,66,93,120$ and $79 \%$ higher compared to the control treatment at 38 DAS where $20,40,60,80$ and $100 \%$ soil were replaced by beverage sludge respectively. Similarly, Okra plant grew 34, 41, 52, 125 and $71 \%$ higher than the control treatment at 49 DAS while the same percentage of sludge was used. The maximum yield of Indian Spinach and Okra was $10.88 \mathrm{~kg} \mathrm{sqm}^{-1}$ and $498.9 \mathrm{~g} \mathrm{plant}^{-1}$ (14 fruit plant ${ }^{-1}$ ) with the treatment of $80 \%$ beverage sludge and $20 \%$ soil which were nine and two times higher than the control treatments. A chronological improvement in food values in terms of ascorbic acid, $\beta$-carotene and protein as well as nutrients ( $\mathrm{Fe}, \mathrm{Ca}, \mathrm{Mg}, \mathrm{K}, \mathrm{P}$ and $\mathrm{Zn}$ ) has been observed with the increase in volume of beverage sludge in pots. This clearly implies the positive effects of beverage sludge on cultivation as a substitute for harmful chemical fertilizer that poses environmental degradation. However, nutrients and food values of cultivated vegetables grown from the media of containing $80 \%$ beverage sludge and $20 \%$ soil are found to be almost similar to good quality Indian Spinach and Okra according to USDA.

A combination of $80 \%$ beverage sludge and $20 \%$ cultivable soil is better than any other combinations when it comes to growth, yield, food value and nutrient uptake by Indian Spinach and Okra. The utilization of beverage sludge as a substitute for fertilizers may be a suitable and sustainable practice towards reducing chemical fertilizer use resulting in minimization of waste.

\section{Declarations}

\section{Acknowdgement}

Authors wish to thank PRAN Foods Ltd. for providing beverage sludge in this study. We would also like to acknowledge Mr. Wasif Ashraf and B. K. Karmaker for assisting in collecteing beverage sludge and shaing overview of ETP of beverage wastewater.

\section{Authors' contributions}


Md. Abul Hasanath conducted conceptualization, methodology, data collection, analysis, writing, review and editing. Ganesh Chandra Saha and Md. Siddique Alam supervised the environmental enginneing and agricultural phenomenas respectively. Md. Nashir Uddin conducted data visualization. All authors read and approved the final manuscript.

\section{Funding}

This work was financially supported by the Committee of Advance Study and Researches (CASR) of Dhaka University of Engineering \& Technology, Gazipur, Bangladesh through the R\&E research grant of post graduate program.

\section{Availability of data and materials}

On reasonable request, the corresponding author may provide all data produced or analyzed during this research.

\section{Competing interests}

The authors declare they have no competing interests.

\section{Authors' information}

${ }^{1}$ Department of Civil Engineering, Dhaka University of Engineering \& Technology, Gazipur, Gazipur-1707, Bangladesh. ${ }^{2}$ Horticulture Research Center, Bangladesh Agricultural Research Institute, Joydebpur, Gazipur, Banladesh.

\section{References}

1. Cision, "Non-alcoholic Drinks Market Size To Expand at 5.3\% CAGR By 2025, Owing to High Demand for Nutritional Beverages | Million Insights," Cision Distribution PR Newswire, Sep. 01, 2020. https://www.prnewswire.com/news-releases/non-alcoholic-drinks-market-size-to-expand-at-5-3-cagrby-2025-owing-to-high-demand-for-nutritional-beverages--million-insights-301121648.html (accessed Apr. 08, 2021).

2. S. Abdelazim, M. Masoud, and M. Youssif, "Micronutrients for Natural Carbonated and Noncarbonated Soft Drink," J. Nutr. Heal. Food Eng., vol. 7, no. 1, pp. 204-212, 2017, doi: 10.15406/jnhfe.2017.07.00226.

3. J. T. Coster, "Soft Drink Industry," Encyclopedia: Dictionary of American History, 2020. encyclopedia.com/history/dictionaries-thesauruses-pictures-and-press-releases/soft-drink-industry (accessed Sep. 24, 2020).

4. K. Valta, T. Kosanovic, D. Malamis, K. Moustakas, and M. Loizidou, "Water Consumption and Wastewater Generation and Treatment in the Food and Beverage Industry," Desalin. Water Treat., vol. 53, no. 12, pp. 1-10, 2014, doi: 10.1080/19443994.2014.934100. 
5. J. Liu, M. Wang, L. Yang, S. Rahman, and S. Sriboonchitta, "Agricultural productivity growth and its determinants in south and southeast Asian countries," Sustain., vol. 12, no. 12, pp. 1-2, 2020, doi: $10.3390 /$ su 12124981.

6. E. Najafi, N. Devineni, R. M. Khanbilvardi, and F. Kogan, "Understanding the Changes in Global Crop Yields through Changes in Climate and Technology," Earth's Futur., vol. 6, no. 3, pp. 410-427, 2018, doi: 10.1002/2017EF000690.

7. CRI, "The Bangladesh model in agriculture growth," Center for Research and Information (CRI), Dhaka, Bangladesh, 2018. [Online]. Available: http://cri.org.bd/publication/Agriculture-bn/TheBangladesh-Model-in-Agriculture-Growth.pdf.

8. MOF, "Bangladesh Economic Review 2019," Ministry of Finance (MOF), Government of the People's Republic of Bangladesh, Dhaka, Bangladesh, 2019. [Online]. Available: https://mof.gov.bd/site/page/44e399b3-d378-41aa-86ff8c4277eb0990/BangladeshEconomicReview.

9. M. S. Islam, “Organic Fertilizers For Sustainable Agriculture," Daily Sun, Dhaka, Jul. 03, 2015.

10. B. Wei, J. Yu, Z. Cao, M. Meng, L. Yang, and Q. Chen, "The Availability and Accumulation of Heavy Metals in Greenhouse Soils Associated with Intensive Fertilizer Application," Int. J. Environ. Res. Public Health, vol. 17, no. 15, pp. 1-13, 2020, doi: 10.3390/ijerph17155359.

11. N. Rodríguez Eugenio et al., "Soil Pollution: A Hidden Reality," Rome, Italy, 2018. Accessed: May 08, 2021. [Online]. Available: http://www.fao.org/3/i9183en/i9183en.pdf.

12. PRAN, “Global Footprint," PRAN-RFL Group Ltd., 2020. https://www.pranfoods.net/globalreach/global-footprint (accessed Apr. 09, 2021).

13. BSMRAU, "Digital Herbarium of Crop Plants," Department of Crop Botany, Bangabandhu Sheikh Mujibur Rahman Agricultural University (BSMRAU), 2019. http://dhcrop.bsmrau.net/varietiesreleased/varieties-released-by-bari/?doing_wp_cron=1571374356.1232869625091552734375 (accessed Oct. 18, 2019).

14. ASTM, "Standard Test Methods for Specific Gravity of Soil Solids by Water Pycnometer (ASTM D854-14)," 2014.

15. K. Brown and A. Wherrett, "Fact Sheets, Bulk Density - Measurement," Soil Quality Organization, Australia, 2019. http://soilquality.org.au/factsheets/bulk-density-measurement (accessed Jun. 25, 2019).

16. E. O. M. Lean, Soil $p H$ and lime requirement, 2nd ed. American Society of Agronomy, Inc. Soil Science Society of America, Inc., Madison, Wisconsin USA, 1982.

17. V. Ramamoorthi and S. Meena, "Quantification of Soil Organic Carbon - Comparison of Wet Oxidation and Dry Combustion Methods," Int. J. Curr. Microbiol. Appl. Sci., vol. 7, no. 10, pp. 146-154, 2018, doi: 10.20546/ijcmas.2018.710.016.

18. D. W. Nelson and L. E. Sommers, "Total Carbon, Organic Carbon, and Organic Matter," in Methods of Soil Analysis, Part 2, Chemical and Microbiological Properties, 2nd ed., A. L. Page, R. H. Miller, and D. R. Kenney, Eds. American Society of Agronomy Inc., Madison, WI, USA., 1982, pp. 539-579. 
19. J. M. Bremmner and C. S. Mulvaney, "Total Nitrogen," in Methods of soil analysis, Part 3, Chemical and microbiological properties, 1st ed., A. L. Page, R. H. Miller, and D. R. Keeney, Eds. Wisconsin, America: Soil Science Society of America, 1982, pp. 595-624.

20. R. H. Bray and L. T. Kurtz, “Determination of Total, Organic, and Available Forms of Phosphorus in Soils," IIlinois Agricultural Experiment Station, Urbana IL, 1945. http://garfield.library.upenn.edu/classics1987/A1987J041400001.pdf (accessed Feb. 15, 2020).

21. D. E. Barker and N. H. Suhr, "Atomic Absorption and Flame Emission Spectrometry," in Methods of soil analysis. Part 2- Chemical and microbiological properties (2nd Edition), 2nd ed., A. L. Page, R. H. Miller, and D. R. Kenney, Eds. Madison, Wisconsin, USA: American Society of Agronomy, Inc., 1982, pp. 13-26.

22. M. A. Tabatabai, "Sulfur," in Methods of soil analysis. Part 2-Chemical and microbiological properties (2nd Edition), 2nd ed., A. L. Page, R. H. Miller, and D. R. Kenney, Eds. Madison, Wisconsin, USA: American Society of Agronomy, Inc., 1982, pp. 501-534.

23. A. Santoro, A. Held, T. P. J. Linsinger, A. Perez, and M. Ricci, “Comparison of Total and Aqua Regia Extractability of Heavy Metals in Sewage Sludge: The Case Study of A Certified Reference Material," TrAC - Trends Anal. Chem., vol. 89, pp. 34-40, 2017, doi: 10.1016/j.trac.2017.01.010.

24. S. Ranganna, "Vitamins," in Handbook of Analysis and Quality Control for Fruit and Vegetable Products, Second., Delhi: Tata McGraw Hill Publication, 1986, pp. 105-106.

25. T. A. Fashanu et al., "Effect of Wood Ash Treatment on Quality Parameters of Matured Green Tomato Fruit (Solanum lycopersicum L.) During Storage," J. Exp. Agric. Int., vol. 29, no. 4, pp. 1-11, 2019, doi: 10.9734/jeai/2019/46042.

26. A. M. Magomya, J. A. and Kubmarawa, D, Ndahi, and G. G. Yebpella, “Determination Of Plant Proteins Via The Kjeldahl Method And Amino Acid Analysis: A Comparative Study," Int. J. Sci. Technol. Res., vol. 3, no. 4, pp. 68-72, 2014.

27. H. K. Maehre, L. Dalheim, G. K. Edvinsen, E. O. Elvevoll, and I. J. Jensen, "Protein DeterminationMethod Matters," Foods, vol. 7, no. 1, p. 5, Jan. 2018, doi: 10.3390/foods7010005.

28. USDA-NRCS, “Soil Bulk Density, Moisture, Aeration- Soil Quality Kit,” United States Department of Agriculture (USDA), 2012. doi: 10.1108/nfs.2012.01742daa.005.

29. I. Moss, "The Why and How to Testing the Electrical Conductivity of Soils," Farm Agronomy and Resource Management (FARM), 2015. https://farmagronomy.com.au/the-why-and-how-to-testingthe-electrical-conductivity-of-soils/ (accessed Mar. 23, 2020).

30. E. D. Lund, "Soil Electrical Conductivity," in Soil Science: Step-by-Step Field Analysis, S. Logsdon, D. Clay, D. Moore, and T. Tsegaye, Eds. American Society of Agronomy and Soil Science Society of America, Madison, WI, USA: American Society of Agronomy and Soil Science Society of America, 2008, pp. 137-146.

31. N. Hossain, M. Islam, M. Alamgir, and M. G. Kibria, "Growth Response of Indian Spinach to Biogas Plant Residues," IOSR J. Pharm. Biol. Sci., vol. 9, no. 2, pp. 01-06, 2014, doi: 10.9790/300809220106. 
32. R. P. Singh and M. Agrawal, "Use of Sewage Sludge as Fertiliser Supplement for Abelmoschus esculentus plants: Physiological, Biochemical and Growth Responses," Int. J. Environ. Waste Manag., vol. 3, no. 1-2, pp. 91-106, 2009, doi: 10.1504/IJEWM.2009.024702.

33. USDA, "Spinach-Food Data Central Search Results," United States Department of Agriculture (USDA), 2019. https://fdc.nal.usda.gov/fdc-app.html\#/food-details/168462/nutrients (accessed Dec. 18, 2019).

34. USDA, "Okra- Food Data Central Search Results," United States Department of Agriculture (USDA), 2019. https://fdc.nal.usda.gov/fdc-app.html\#/food-details/169260/nutrients (accessed Dec. 21, 2019).

\section{Figures}
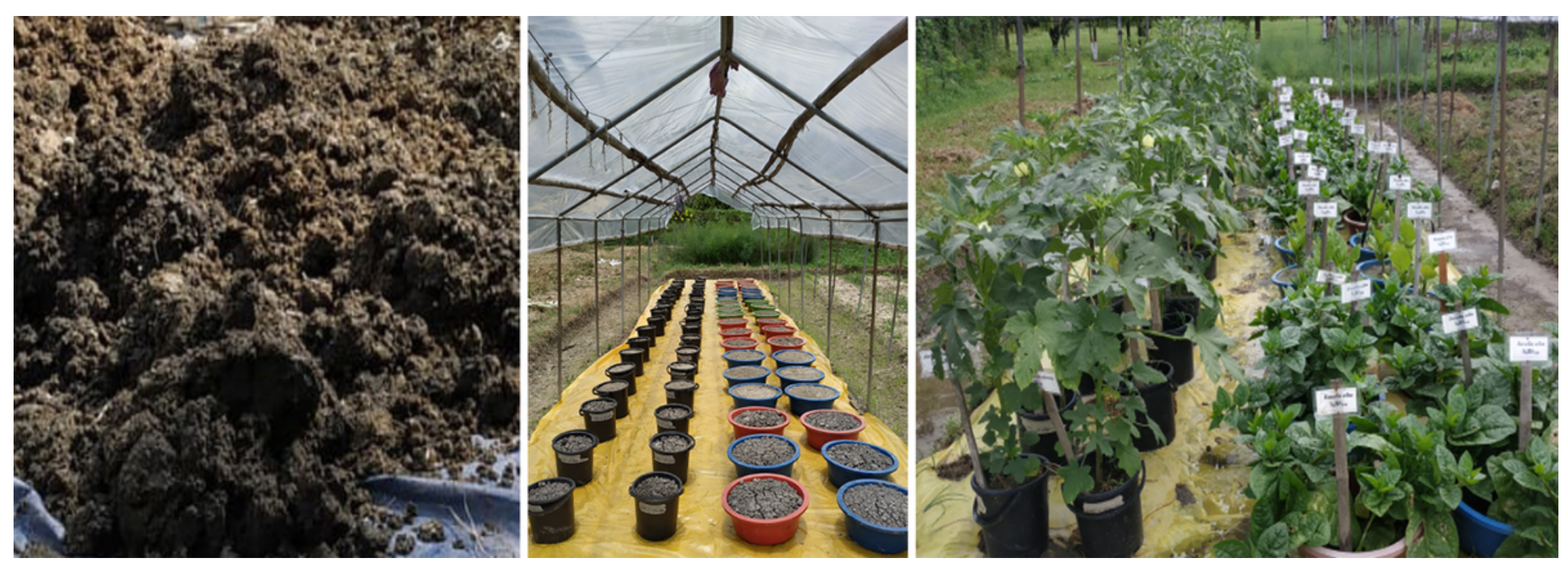

Figure 1

Cultivation using beverage sludge 

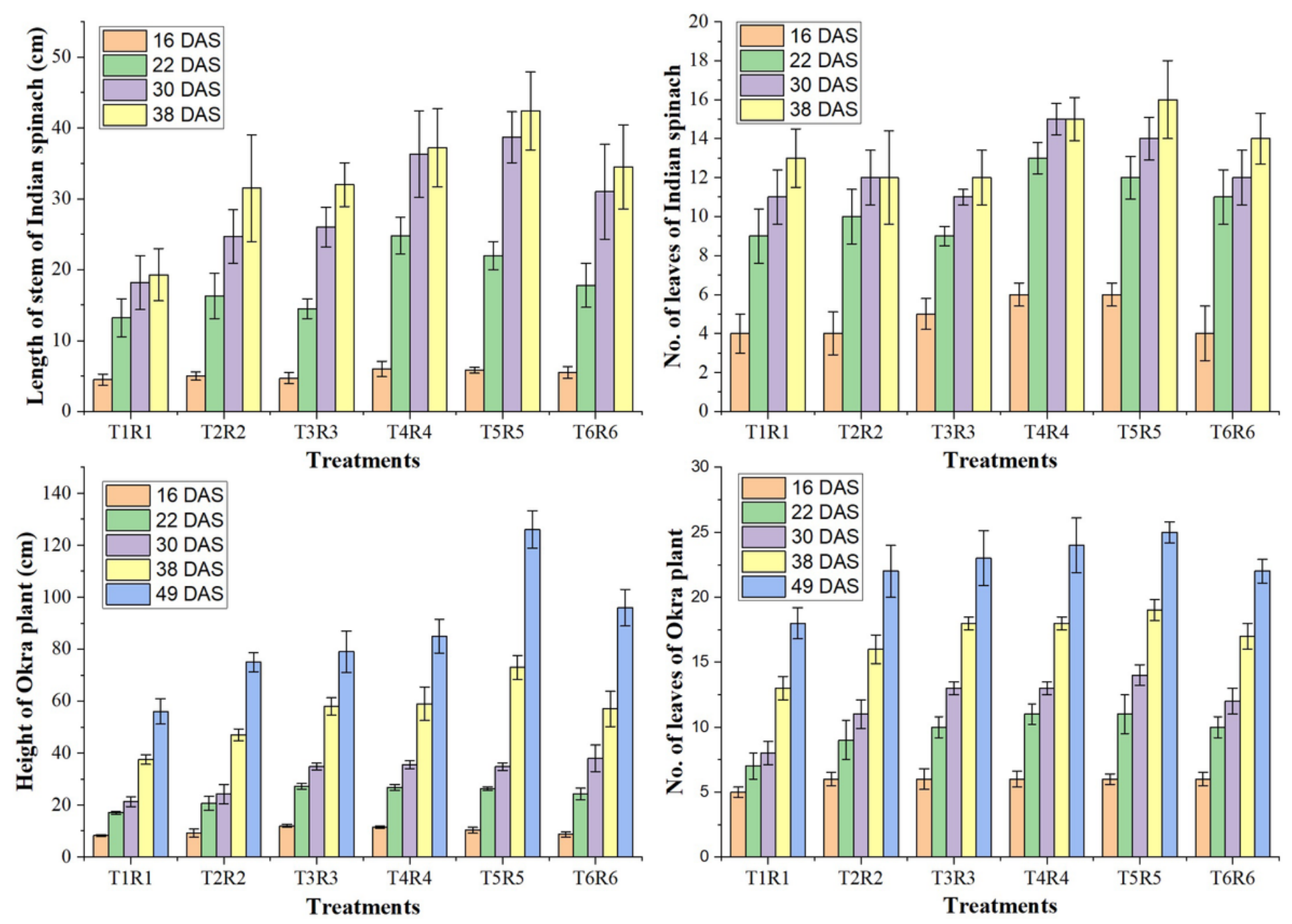

Figure 2

Effect of Effects on growth of Indian spinach and Okra
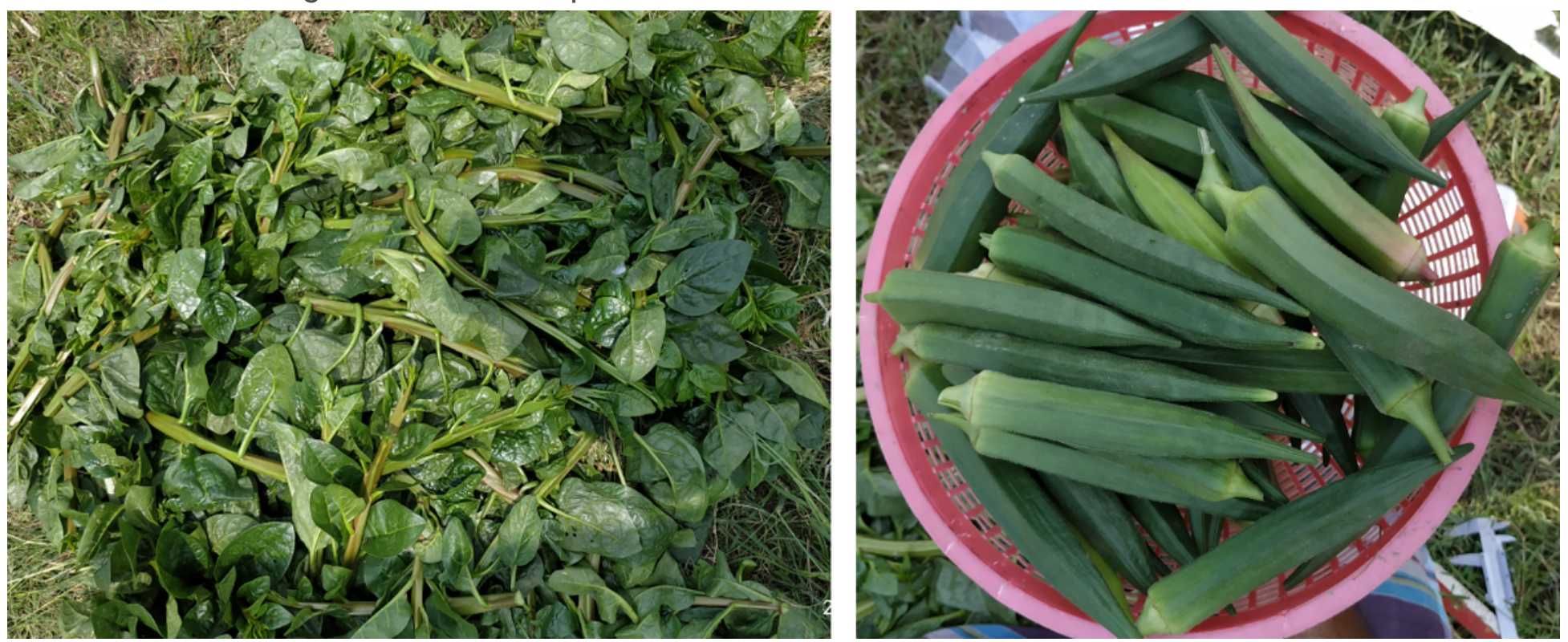

Figure 3 
Harvested vegetables
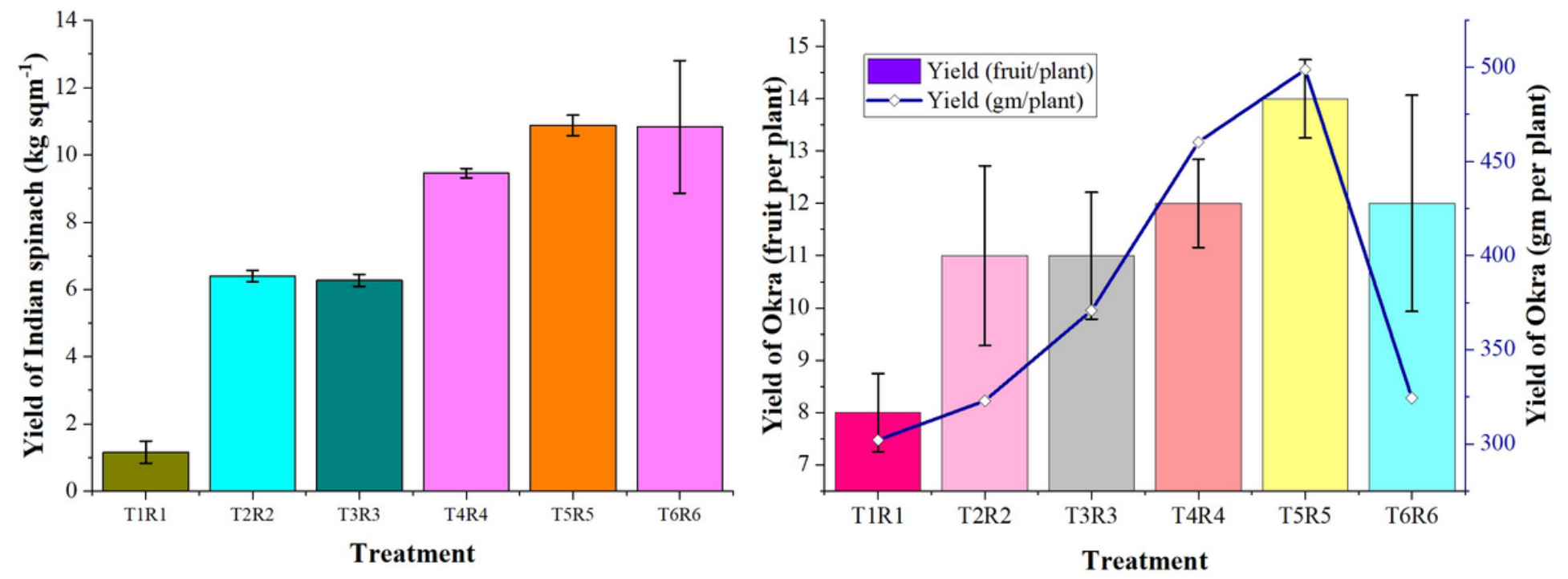

Figure 4

Effects of beverage sludge on yield of cultivates 

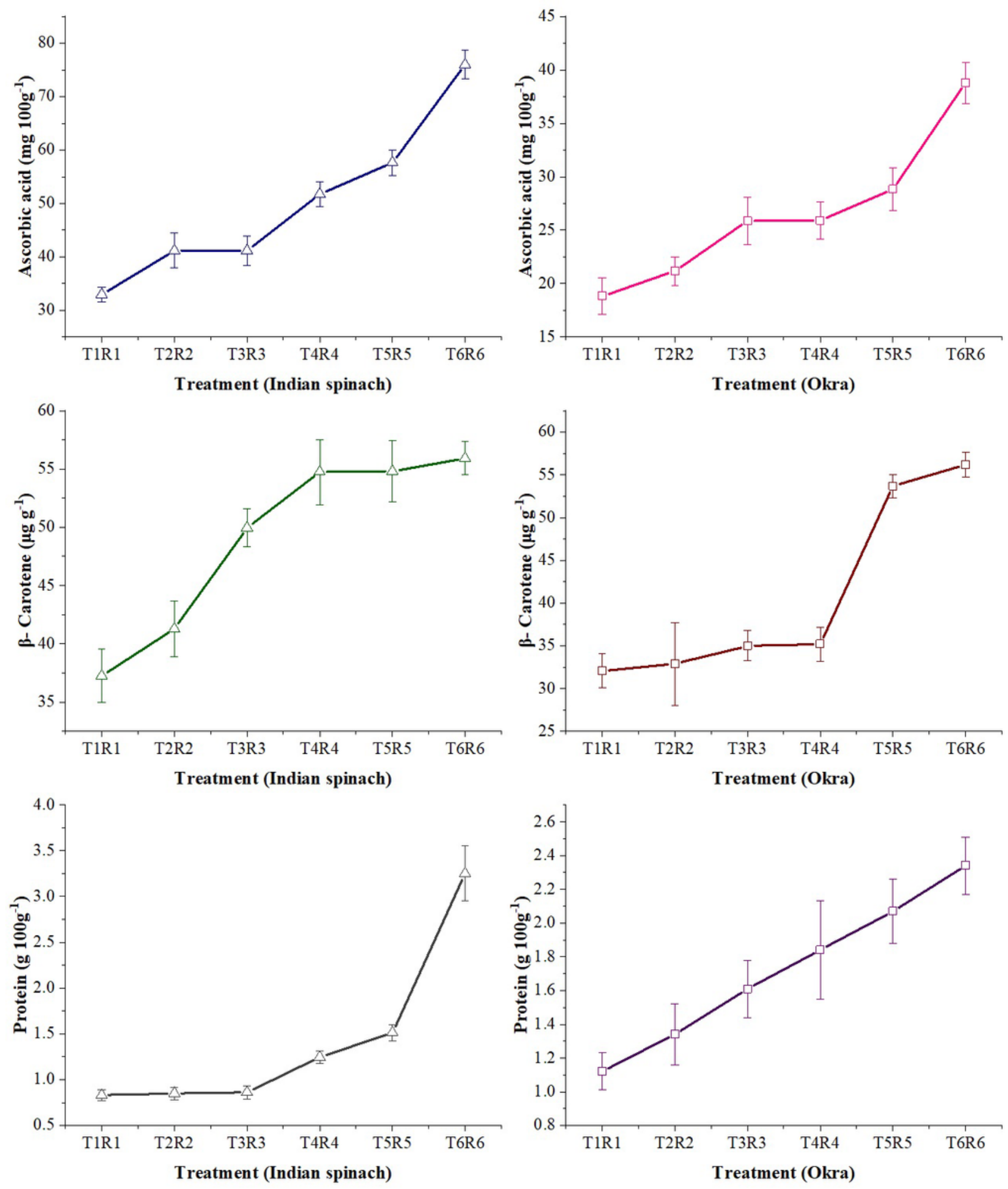

Figure 5

Effects on food values of cultivates 